\title{
NEW INSIGHTS IN THE PATHOGENESIS OF CISPLATIN-INDUCED NEPHROTOXICITY
}

Bojana Djokovic ${ }^{1}$, Marina Gazdic Jankovic ${ }^{2}$, C. Randall Harrell ${ }^{3}$, Crissy Fellabaum ${ }^{3}$, Nebojsa Arsenijevic ${ }^{1}$, and Vladislav Volarevic ${ }^{1}$ ${ }^{1}$ Department of Microbiology and Immunology, Center for Molecular Medicine and Stem Cell Research, Faculty of Medical Sciences, University of Kragujevac, , Kragujevac, Serbia

${ }^{2}$ Department of Genetics, Faculty of Medical Sciences, University of Kragujevac, 69 Svetozara Markovica Street, Kragujevac, Serbia

${ }^{3}$ Regenerative Processing Plant, LLC, 34176 US Highway 19 N Palm Harbor, Palm Harbor, Florida, United States of America

\section{NOVI UVIDI U PATOGENEZU NEFROTOKSIČNOSTI IZAZVANE \\ CISPLATINOM \\ Bojana Đoković ${ }^{1}$, Marina Gazdić Janković², C. Randall Harrell ${ }^{3}$, Crissi Fellabaum ${ }^{3}$, Nebojša Arsenijević ${ }^{1}$ i Vladislav Volarevic ${ }^{1}$ \\ ${ }^{1}$ Klinika za mikrobiologiju i imunologiju, Centar za molekularnu medicinu i istraživanje matičnih ćelija, Fakultet medicinskih nauka, Univerzitet u Kragujevcu, Kragujevac, Srbija \\ ${ }^{2}$ Katedra za genetiku, Fakultet medicinskih nauka, Univerzitet u Kragujevcu, Kragujevac, Srbija \\ ${ }^{3}$ Regenerativno postrojenje za prerardu, LLC, 34176 US Highvai 19 N Palm Harbor, Palm Harbor, Florida, Sjedinjene Američke Države}

\begin{abstract}
Cisplatin (cis-diamminedichloroplatinum II) is a widely used chemotherapeutic agent. However, efficacy and clinical utility of this drug is significantly limited by severe side effects such as nephrotoxicity which develops due to renal accumulation and biotransformation in proximal tubular epithelial cells. Cisplatin-induced nephrotoxicity can be manifested as acute kidney injury (AKI), or as different types of tubulopathies, salt wasting, loss of urinary concentrating ability, and magnesium wasting. The attenuation of cisplatin-caused AKI is currently accomplished by hydration, magnesium supplementation or mannitol-induced forced diuresis. However, mannitol treatment causes over-diuresis and consequent dehydration, indicating an urgent need for the clinical use of newly designed, safe and efficacious renoprotective drug, as an additive therapy for high dose cisplatin-treated patients. Accordingly, we emphasized current knowledge regarding molecular mechanisms responsible for cisplatin-caused nephrotoxicity and we described in detail the main clinical manifestations of cisplatin-induced renal dysfunction in order to pave the way for the design of new therapeutic approaches that can minimize detrimental effects of cisplatin in the kidneys. Having in mind that most of cisplatin-induced cytotoxic effects against renal cells are, at the same time, involved in anti-tumor activity of cisplatin, new nephroprotective therapeutic strategies have to prevent renal injury and inflammation without affecting cisplatin-induced toxicity against malignant cells.
\end{abstract}

Keywords: cisplatin, nephrotoxicity, acute kidney injury, apoptosis, inflammation.

\section{SAŽETAK}

Cisplatin (engl. cis-diamminedichloroplatinum II) je široko korišćen hemioterapeutik. Međutim, efikasnost $i$ klinička primena ovog leka je značajno ograničena teškim neželjenim efektima kao što je nefrotoksičnost, koja nastaje usled akumulacije cisplatina u bubrezima i biotransformacije u epitelnim ćelijama proksimalnih tubula. Nefrotoksičnost izazvana cisplatinom se može manifestovati akutnim oštećenjem bubrega, različitim tipovima tubulopatija, gubitkom soli i magnezijuma ili gubitkom sposobnosti koncentrisanja urina. Smanjenje akutnog oštećenja bubrega izazvanog cisplatinom se trenutno postiže hidracijom, dodatkom magnezijuma ili forsiranom diurezom izazvanom manitolom. Međutim, lečenje manitolom uzrokuje prekomernu diurezu i posledičnu dehidraciju, što ukazuje na hitnu potrebu za kliničkom upotrebom novog, sigurnog $i$ delotvornog renoprotektivnog leka, kao dodatne terapije za pacijente lečene visokom dozom cisplatina. U skladu sa tim, naglasili smo sadašnja saznanja o molekularnim mehanizmima odgovornim za nefrotoksičnost izazvanu cisplatinom $i$ detaljno smo opisali glavne kliničke manifestacije bubrežne disfunkcije izazvane cisplatinom kako bi se otvorio put za dizajniranje novih terapijskih pristupa koji mogu minimizirati štetne efekte cisplatina u bubrezima. Imajući u vidu da je većina citotoksičnih efekata cisplatina na ćelijama bubrega istovremeno uključena $u$ antitumorsku aktivnost cisplatina, nove nefroprotektivne terapijske strategije moraju sprečiti oštećenje bubrega $i$ zapaljenje, bez uticaja na toksični efekat cisplatina na maligne ćelije.

Ključne reči: cisplatin, nefrotoksičnost, akutno oštećenje bubrega, apoptoza, zapaljenje.

\section{sciendo}




\section{ABBREVIATIONS}

AKI: Acute kidney injury;

PTEC: Proximal tubular epithelial cells;

DNA: Deoxyribonucleic acid;

Ctr: Copper transporter;

ATP7A and ATP7B: P-type copper-transporting

ATPases;

OCT2: Organic cation transporter 2;

MATE1: Multidrug extrusion transporter 1;

GGT: Gamma glutamyl transpeptidase;

NER: Nucleotide excision repair;

MMR: Mismatch repair;

ROS: Reactive oxygen species;

CYP: Cytochrome

P450 system;

AIF: Apoptosis-inducing factor;

ER: Endoplasmic reticulum;

ER-iPLA2: Ca2+-independent phospholipase A2;

MAPK: Mitogen-activated protein kinase;

ERK: Extracellular signal-regulated kinase;

JNK/SAPK: Jun N-terminal Kinase/Stress-Activated

Pathway Kinase;

Chk2: Checkpoint kinase 2;

ATR: Rad3-related protein;

\section{INTRODUCTION}

Cisplatin (cis-diamminedichloroplatinum II) is one of the most potent antitumor drugs, which is used to treat various types of malignancies, such as head and neck, gastrointestinal, urogenital, breast and lung cancers (1-13). Nevertheless, efficacy of cisplatin is significantly limited by severe side effects, including nephrotoxicity, ototoxicity and myelosuppression $(14,15)$. Cisplatin-induced nephrotoxicity is a result of renal accumulation and biotransformation of cisplatin and is manifested as acute kidney injury (AKI), or as different types of tubulopathies, salt wasting, loss of urinary concentrating ability, and magnesium wasting $(16,17)$. AKI is dosedependent complication, noticed in $25-30 \%$ of cisplatintreated patients (18-20). The attenuation of cisplatin-caused renal injury is currently accomplished by hydration, magnesium supplementation or by mannitol-induced forced diuresis (20). However, mannitol treatment may cause over-diuresis and consequent life-treating dehydration (16), indicating an urgent need for the clinical implementation of newly designed, safe and efficacious nephroprotective drug, as an additive therapy for cisplain-treated patients. Until now, amifostine [(ethanethiol, 2-[(3-aminopropyl)amino] dihydrogen phosphate ester)] was most usually used against cisplatin-induced renal injury, but its adverse effects, such as ototoxicity, hypotension, vertigo, hypocalciemia, nausea and vomiting, significantly limited its clinical use $(16,17)$. Accordingly, there still remains an unmet need for the development of new, nephroprotective agent against cisplatin-caused AKI. Having in mind that most of cisplatin-induced cytotoxic effects against renal cells are, at the same time, involved in anti-tumor activity of cisplatin (13), this new, nephroprotective agent will have to prevent AKI without affecting cisplatin-induced toxicity against malignant cells. Design of novel therapeutic strategies against cisplatin-provoked nephrotoxi-
PUMA- $\alpha$ : $p 53$ upregulated modulator of apoptosis; TauT: Taurine transporter;

Bcl-2: B-cell lymphoma 2;

Atg5: Autophagy-related protein-5;

LC3: Microtubule-associated protein light chain 3;

RIP1: Receptor-interacting protein 1;

MLKL: Mixed lineage kinase domain-like protein;

TNF- $\alpha$ : Tumor necrosis factor alpha;

TLR: Toll like receptor;

IL: Interleukin;

TNFR: Tumor necrosis factor receptor;

ICAM-1: Intercellular adhesion molecule-1;

IFN- $\gamma$ : Interferon-gamma;

Tregs: Regulatory T cells;

NK cells: Natural killer cells;

NO: Nitric oxide;

Mincle: Macrophage-inducible C-type lectin;

MIF: Macrophage migration inhibitory factor;

CD: Cluster of differentiation;

CXCL1: Chemokine (C-X-C motif) ligand 1;

DCs: Dendritic cells;

FoxP3: Forkhead box P3;

Tim-1: T cell immunoglobulin mucin 1;

Kim-1: Kidney injury molecule-1.

city requires understanding of molecular mechanisms which are involved in cisplatin-induced renal injury and inflammation and which are responsible for the development of main clinical manifestations and complications of cisplatin treatment. Accordingly, in this review article, we emphasized current knowledge about signaling pathways and cellular mechanisms which are responsible for the development of renal inflammation and activation of detrimental immune response elicited after cisplatin-caused injury of proximal tubular epithelial cells (PTECs). Additionally, herewith we described in detail the main clinical manifestations of cisplatin-induced renal dysfunction in order to pave the way for the design of new therapeutic approaches that can minimize detrimental effects of cisplatin in the kidneys. Our hope is that clinicians and scientists will use information presented herein as a starting point for the design of novel, effective nephroprotective strategies against cisplatin-induced nephrotoxicity.

\section{Molecular mechanisms responsible for the development of cisplatin-induced nephrotoxicity}

Cisplatin is mainly excreted by the kidneys, by both glomerular filtration and tubular secretion (21). During renal excretion cisplatin accumulates in the kidneys, and levels of this drug in PTECs are about five times greater than in the blood (18). Accordingly, toxic effects occur primarily in PTECs $(21,22)$. The copper transporter 1 and 2 (Ctr1 and Ctr2), the P-type copper-transporting ATPases (ATP7A and ATP7B), the organic cation transporter 2 (OCT2), and the multidrug extrusion transporter 1 (MATE1) are the most important membrane transporters involved in the cellular uptake of cisplatin (23). Although cisplatin may enter PTEC through passive diffusion, Ctr1 and OCT2-mediated uptake of cisplatin are mainly responsible for the import of cisplatin in PTECs and for high accumulation of cisplatin in the kidneys (21). 
Accordingly, genetic deletion of Ctr1 significantly reduced cisplatin-induced apoptosis of PTECs (24). Similarly, deficiency of OCT2 notably attenuated toxicity of cisplatin (25), while cimetidine, an OCT2 substrate, reduced cisplatin uptake by PTECs and alleviated nephrotoxicity (26).

Cisplatin-induced toxicity is a consequence of cisplatin conversion into several nephrotoxic molecules within the PTECs. Several studies have shown that glutathione-conjugate of cisplatin in the kidneys is metabolized via gamma glutamyl transpeptidase (GGT) expressed on the surface of PTECs. These conjugates are further degradated into highly reactive thiols by the activity of aminopeptidase $\mathrm{N}$ (APN) and cisteine-S-conjugate beta-lyase (CCBL). Since among all tissues, GGT, APN and CCBL have the highest activity in the kidneys, these enzymes were considered as potential targets for the attenuation of cisplatin-induced nephrotoxicity $(20,27)$. Accordingly, several ongoing experimental and clinical trials investigate potential therapeutic effects of GGT, APN and CCBL inhibition as new approach for alleviation of cisplatin-induced AKI.

Once cisplatin enters the PTECs, it forms intrastrand crosslinks among two adjacent guanine residues within DNA affecting replication and transcription which results in the activation of DNA repair mechanisms. Accordingly, an increased activity of nucleotide excision repair (NER) and mismatch repair (MMR) system has been associated with resistance to cisplatin-induced AKI and enhancement of NER and MMR system activity is considered a new approach for prevention of cisplatin-induced AKI (28).

In addition, regulators of cell cycle play an important role in the development of cisplatin-induced AKI and these molecules could also be taken into account as potential targets for prevention of cisplatin-induced renal injury. After cisplatin administration, normally quiescent kidney cells enter the cell cycle and consequently the cell cycle-inhibitory proteins (p21, 14-3-3 and p27), which coordinate cell cycle and play a protective role against toxicity, become induced. Accordingly, deletion of the p21 or 14-3-3 genes resulted in enhanced nephrotoxicity elicited by cisplatin (29-31). Since cisplatin treatment causes an increased activity of Checkpoint kinase 2 (Cdk2), p21-mediated protection from cisplatin-induced injury is relied on inhibition of Cdk2 (32). Accordingly, several lines of evidence suggested the importance of Cdk2-inhibitory drugs in prevention of cisplatin-induced nephrotoxicity (32).

Oxidative stress is crucially involved in cisplatin-induced AKI. Within the cell, cisplatin is converted into a highly reactive form, which can rapidly react with thiol-containing antioxidant molecules, such as glutathione, methionine and metallothionein $(33,34)$. Consequently, depletion of glutathione and similar antioxidants leads to increased accumulation of endogenous reactive oxygen species (ROS) resulting in induction of oxidative stress within cisplatin-injured PTECs. ROS may target and modify cell components, including lipids, proteins, and DNA, resulting in cellular stress (35). Additionally, cisplatin may promote ROS generation by direct binding to P450 (CYP) system in microsomes $(18,36)$ or may induce mitochondrial dysfunction by distorting respiratory chain (37). In line with these observations, several studies demonstrated that treatment with antioxidants significantly attenuated cisplatin-induced AKI (38-41), indicating crucial role of oxidative stress in the pathogenesis of cisplatin-induced AKI.

Importantly, cisplatin-induced extensive generation of ROS and free radicals in PTECs accelerate production of advanced glycation end products (AGEs) which further contribute to the progression of renal injury and inflammation (35). Since kidneys have a crucial role in AGEs disposal, cisplatininduced renal dysfunction increases AGE levels in injured kidneys resulting in the development of glomerulosclerosis, interstitial fibrosis, and tubular atrophy (35).

Treatment with cisplatin in vivo causes a great increase in both necrosis and apoptosis of PTECs (42). Extrinsic, intrinsic (mitochondrial) and endoplasmic reticulum (ER)-stress pathway are involved in cisplatin-induced AKI. Cisplatin treatment of PTECs resulted in translocation of Bax to mitochondria and releasing of cytohrome c $(43,44)$, apoptosis-inducing factor (AIF) (45) and endonuclease G (46) from mitochondria, accompanied by activation of caspase-3,-8 and 9 (47) and caspase-12 which has been designated as initiator caspase in ER-stress pathway regulated by the expression of calcium-independent phospholipase A2 (ER-iPLA2) (4850).

Cisplatin is known to activate all three mitogen-activated protein kinases (MAPKs) in the kidney, including p38, extracellular signal-regulated kinase (ERK), and Jun N-terminal Kinase/Stress-Activated Pathway Kinase JNK/SAPK (51). The ERK was shown to mediate cisplatin-induced nephrotoxicity via phosphorylation of the proapoptotic p66 shc protein (52). Furthermore, inhibition of ERK resulted in attenuated expression and activation of caspase-3, and consequently decreased apoptosis in cisplatin-treated renal cells (51).

P53 protein has an important role in cisplatin-induced AKI (53-55). Cisplatin treatment induces a DNA damage, leading to the activation of molecular sensor for DNA damage- ataxia telangiectasia and Rad3-related protein (ATR), which activates Chk2. Both ATR and Chk2 can phosphorylate $\mathrm{p} 53$ for its activation. Also, ROS may promote activation of p53 by inducing DNA damage or through ATR, Chk2, nuclear factor kappa B (NF-kB) or p38 activation (53). Activated p53 increases transcription of pro-apoptotic genes, such as PUMA- $\alpha$ and ER-iPLA2, and down-regulates expression of anti-apoptotic genes (p21 and taurine transporter (TauT)) (53-55). Additionally, p53 promotes apoptosis of PTECs through the interactions with Bcl-XL, Bax, Bak proteins in mitochondria and/or cytosol (53) (Figure 1). 
Figure 1. Cisplatin-induced activation of p53 results in apoptosis of tubular cells.

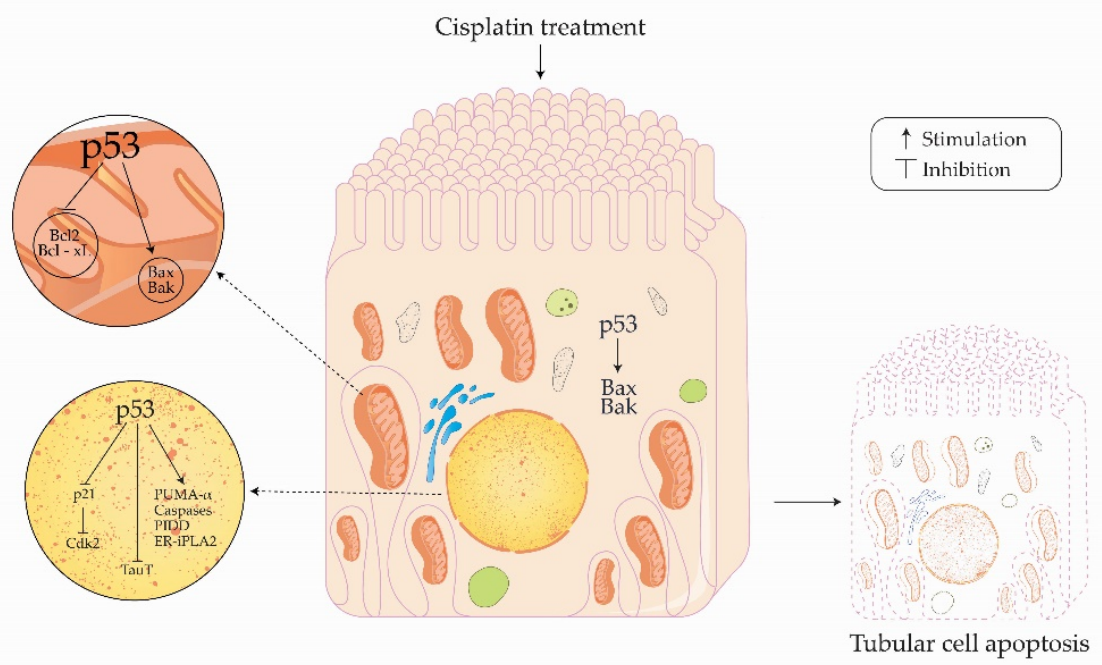

Activated p53 increases transcription of pro-apoptotic genes, such as PUMA- $\alpha$ and ER-iPLA2, and downregulates expression of anti-apoptotic genes (p21 and taurine transporter (TauT)). Additionally, p53 promotes apoptosis of tubular cells through the interactions with Bcl-XL, Bax, Bak proteins in mitochondria and/or cytosol. Abbreviations: Bcl-2: B-cell lymphoma 2; Bcl-xL: B-cell lymphoma-extra large; Bax: Bcl-2-associated X protein; Bak: Bcl-2 homologous antagonist killer; PUMA- $\alpha$ : p53 upregulated modulator of apoptosis; PIDD: p53-induced protein with a death domain; ER-iPLA2: $\mathrm{Ca}^{+}$-independent phospholipase A2; Cdk2: Cyclin-dependent kinase complex; TauT: taurine transporter.

In addition to the regulation of apoptosis, p53 may contribute to the development of cisplatin-caused nephrotoxicity by modulating autophagy which, as an adaptive mechanism, promotes PTECs survival during AKI (56). Within hours after cisplatin administration, markers of autophagy, such as Beclin 1, LC3, and Atg5 are significantly up-regulated in injured PTECs (56-58). Importantly, DNA damage, activation of $\mathrm{p} 53$, and mitochondrial injury are increased in proximal tubules of autophagy-deficient mice, suggesting protective role of autophagy in cisplatin-injured kidneys (57,59-62).

It is important to highlight that, in addition to apoptosis and autophagy, necroptosis was also detected in renal tubules after injection of cisplatin $(63,64)$. Receptor-interacting protein 1 (RIP1) and mixed lineage kinase domain-like protein (MLKL) - deficiency, as well as pharmacological inhibition of necroptosis, significantly reduced cisplatin-induced AKI $(63,64)$.

\section{The important role of inflammation in the development of cisplatin-induced aki}

Inflammation plays a key role in the progression of cisplatin-induced AKI (65-72). After cisplatin treatment, several alarmins are produced by injured renal cells such as mesangial cells, glomerular cells, endothelial and renal tubular cells which can initiate enhanced production of inflammatory cytokines (70). Among them, tumor necrosis factor alpha (TNF- $\alpha$ ) was significantly elevated in the serum as well as urine of cisplatin-treated animals, indicating important pathophysiological role of TNF- $\alpha$ in cisplatin-induced nephrotoxicity $(65,66)$. The biological activities of TNF- $\alpha$ are mediated by two different receptors, TNFR1 and TNFR2 (71,72). Although TNFR1 was responsible for TNF- $\alpha-$ induced systemic and anti-tumor effects (71), several lines of evidence demonstrated that TNFR2 rather than TNFR1 mediates cytotoxic and inflammatory actions of TNF- $\alpha$ in cisplatin-injured kidneys (72). Accordingly, inhibition of TNFR2 should be further explored in up-coming experimental studies as a potentially new therapeutic approach that could reduce AKI without affecting anti-tumor effects of cisplatin mediated by TNF- $\alpha$.

Some research demonstrated an important role of TLR-4 for enhanced production of TNF- $\alpha$ in resident and renal-infiltrating immune cells. One of possible endogenous molecules which can bind TLR-4 and initiate an innate immune response after cisplatin-treatment is gp96, which is increased after cisplatin administration (68). Activation of TLR-4 promotes p38 MAPK dependent signaling which induces enhanced secretion of TNF- $\alpha$ in cisplatin-injured kidneys $(67,68)$. In addition to TLR-4 dependent production of TNF$\alpha$, cisplatin treatment also activates inflammasome complex in renal infiltrated leukocytes, resulting in enhanced secretion of interleukin (IL)-1 $\beta$ (69).

Elevated levels of TNF- $\alpha$ and IL- $1 \beta$ are isially accompanied with enhanced production of other inflammatory cytokines, particularly IL-18, and IL-6 resulting in the increased recruitment of circulating immune cells into cisplatin-injured kidneys (73-76). Intercellular adhesion molecule-1 (ICAM1) has been considered a crucially important adhesion 
molecule for migration of immune cells into cisplatin-injured kidneys since the inhibition of this integrin significantly reduced total number of renal-infiltrated leukocytes (77).

Although expression of IFN- $\gamma$, well known inflammatory cytokine, is increased in cisplatin-injured kidneys, neutralization of this cytokine had no impact on renal dysfunction, suggesting the existence of IFN- $\gamma$-independent development of cisplatin-induced AKI (78). Recently published studies indicated important pathogenic role of IL-33 in cisplatin-induced AKI. Serum levels of IL-33 were increased in cisplatin-injured animals. Mice with cisplatin-induced AKI injected with fusion protein, which neutralized IL-33, had a significant decrease in creatinine, pathohistological score, and showed reduced apoptosis of cisplatin-induced PTECs, while injection of recombinant IL-33 notably aggravated cisplatin-induced AKI (79).

IL-10 is a cytokine with potent anti-inflammatory properties that suppresses the activation of leukocytes and the production of proinflammatory cytokines and chemokines in cisplatin-injured kidneys (80). Several studies demonstrated that IL-10, secreted mainly by regulatory $\mathrm{T}$ cells (Tregs), tolerogenic dendritic cells, and alternatively activated macrophages, reduces cisplatin nephrotoxicity, and may act, in part, by inhibiting the maladaptive activation of genes that cause leukocyte activation and adhesion, and induction of iNOS $(78,80-82)$.

Different types of immune cells, including neutrophils, macrophages, mast cells, natural killer (NK) cells, T and B cells produce inflammatory cytokines or anti-inflammatory IL-10 and other immunomodulatory factors which play an important role in the pathogenesis of cisplatin-induced AKI (Figure 2).

Mast cells have important pathogenic role in cisplatin-induced nephrotoxicity. Depletion of mast cells resulted in significantly reduced renal injury in cisplatin-treated mice (82). Deficiency of mast cells was accompanied by lower number of renal-infiltrated leukocytes and notably down-regulated serum levels of TNF- $\alpha$, suggesting that mast cells mediated cisplatin-induced AKI by promoting recruitment of circulating immune cells in the kidneys in TNF- $\alpha$-dependent manner $(82,83)$.

Renal-infiltrated neutrophils produce large amounts of ROS, proteases, and inflammatory cytokines, leading to renal epithelial injury (84-86). In contrast, an inhibition of TNF- $\alpha$ or TLR-4 signaling pathways, administration of IL-10 as well as inhibition of ICAM-1 $(68,77,80,87)$ are associated with a decreased number of activated neutrophils in renal parenchyma of cisplatin-treated animals which corresponds to the attenuation of renal injury and inflammation. It has to be noted that neutrophils, which infiltrate cisplatin-injured kidneys, may alter their inflammatory phenotype depending on the cross-talk with immunosuppressive cells (86).
Figure 2. Immunomodulatory molecules which expression is enhanced in renal parenchymal and immune cells upon cisplatin treatment.

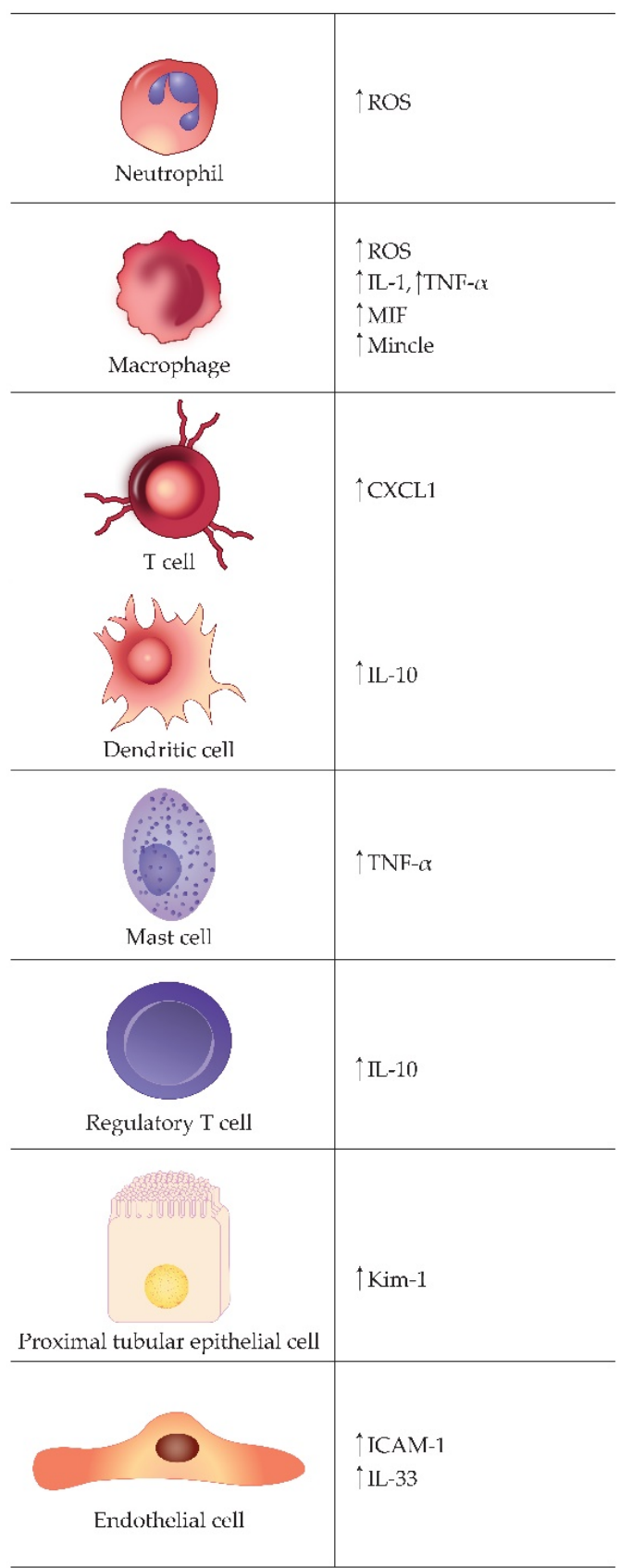

Cisplatin treatment induces enhanced expression of reactive oxygen species (ROS), inflammatory cytokines and chemokines as well as integrins in the kidneys enabling crosstalk between cisplatin-injured proximal tubular epithelial cells, endothelial cells and renal-infiltrated innate and adaptive immune cells. Abbreviations: ROS: Reactive oxygen species; IL: Interleukin; TNF- $\alpha$ : Tumor necrosis factor alpha; MIF: Macrophage migration inhibitory factor; Mincle: Macrophage-inducible C-type lectin; CXCL1: Chemokine (C-X-C motif) ligand 1; Kim-1: Kidney injury molecule-1; ICAM-1: Intercellular adhesion molecule-1. 
Tolerogenic renal DCs and T regulatory cells (Tregs), in juxtracrine and paracrine manner, promote enhanced expression of IL-10 in renal-infiltrated neutrophils resulting in their differentiation into immunosuppressive and anti-inflammatory cells. Accordingly, depletion of neutrophils as well as their adoptive transfer may result in either alleviation or aggravation of cisplatin-induced AKI, depending on the cellularmake up and microenvironment of the cisplatin-injured kidneys (86).

Macrophages play an important inflammatory role in the initial phase of cisplatin-caused AKI. Cisplatin treatment induces activation of inflammasome, p38 MAPK and NF-kB pathways in renal macrophages resulting in enhanced production of superoxide anions, nitric oxide (NO), IL-1 and TNF- $\alpha(73,89)$. In addition, cisplatin-induced activation of TLR-4 induces expression of macrophage-inducible C-type lectin (Mincle) in renal infiltrating macrophages. Mincle promotes generation of inflammatory M1 macrophages which are capable to produce large amounts of inflammatory cytokines. Accordingly, cisplatin-induced activation of Mincle on macrophages results in exacerbation and progression of renal inflammation (90). In line with these findings, suppressed expression of Mincle on renal macrophages completely abrogates their inflammatory phenotype and adoptive transfer of Mincle-silenced macrophages protects against cisplatin-induced nephrotoxicity (90). Accordingly, Mincle is considered a potential molecular target for macrophage dependent attenuation of cisplatin-induced AKI and its therapeutic potential is going to be explored in future experimental studies. In addition to Mincle, macrophage migration inhibitory factor (MIF) plays an important pathogenic role in cisplatin-induced nephrotoxicity. Deletion of MIF suppressed influx of M1 macrophages and reduced concentration of macrophagederived inflammatory cytokines and chemokines in the kidneys, attenuated recruitment of circulating immune cells in the cisplatin-injured kidneys which resulted in alleviation of AKI (91).

CD4+ and CD8+ T cells are crucially important in orchestrating immune response during cisplatin-induced AKI $(66,79,92)$. Cisplatin-injured renal cells release IL-33 which activates CD4+ T cells and increase production of inflammatory cytokines, such as TNF- $\alpha$, and chemokine CXCL1 (79). CXCL1 induces enhanced recruitment of neutrophils and may directly induce apoptosis of tubular epithelial cells $(66,79)$. Cisplatin treatment increases expression of Fas receptor on renal tubular cells enabling apoptosis of these cells due to their interaction with FasL expressing renal infiltrating CD8+ T lymphocytes and NK cells (92).

Cisplatin treatment provokes enhanced expression of $\mathrm{T}$ cell immunoglobulin mucin 1 (Tim-1) on PTECs which acts as a costimulatory molecule for activation of renal-infiltrated $\mathrm{T}$ cells (93). Consequently, use of Tim-1-blocking antibody suppressed activation of renal-infiltrated CD4+ helper T cells and their cross-talk with CD8+ cytotoxic T cells, significantly reduced apoptosis of PTECs and protected against cisplatin-induced AKI (93). Due to its important role in the development and progression of AKI, Tim-1 was designated as kidney injury molecule-1 (Kim-1) and has been considered as potential molecular target for the attenuation of $\mathrm{T}$ celldriven renal inflammation (93).

Among immunosuppressive cells, Tregs and tolerogenic DCs have the most important role for the attenuation of detrimental inflammatory response in cisplatin-injured kidneys (94-96). Soon after cisplatin injection, forkhead box P3 (FoxP3)-expressing CD4+CD25+ circulating Tregs migrate into the injured kidneys where, in IL-10 dependent manner, suppress activation of M1 macrophages, inflammatory neutrophils, Th1 and Th17 cells (94). Accordingly, adoptive transfer of Tregs significantly attenuated renal dysfunction and mortality of cisplatin-treated T cell-deficient mice (94). Treg-induced alleviation of cisplatin-caused AKI was accompanied by down-regulated serum levels of inflammatory cytokines (TNF-a and IL-1b), reduced number of M1 macrophages and inflammatory IFN- $\gamma$ and IL-17-producing leukocytes in the injured kidneys, indicating therapeutic potential of Treg-based therapy for attenuation of cisplatin-induced nephrotoxicity.

Tolerogenic DCs represent specific sub-population of resident renal immune cells which have important immunosuppressive and nephroprotective role in cisplatin-induced AKI (95,96). Damage associated molecular patterns (DAMPs) and alarmins, released from cisplatin-injured PTECs, down-regulate expression of costimulatory molecules and enhance expression of anti-inflammatory IL-10 in renal DCs $(78,88,95,96)$. These immunosuppressive DCs, mainly in IL-10 dependent manner, inhibit activation of M1 macrophages, inflammatory neutrophils and Th17 cells in the cisplatin-injured kidneys contributing to the alleviation of inflammation $(78,88,95,96)$. Accordingly, depletion of tolerogenic DCs significantly enhanced inflammatory response in the kidneys and aggravated cisplatin-induced AKI $(88,95)$.

\section{Clinical manifestations of cisplatin-induced renal injury}

Acute renal failure, thrombotic microangiopathy, hypomagnesemia, anemia, salt wasting and Fanconi-like syndrome have been the most usually observed clinical manifestations of cisplatin-induced nephrotoxicity (97).

Generally, acute renal failure begins a few days after cisplatin treatment. It is manifested by an increase in the blood urea nitrogen and serum creatinine concentrations and decrease of glomerular filtration rate. Cisplatin-treated patients usually develop non-oliguric AKI, and glucosuria and minimal proteinuria might be observed as a result of PTEC injury (20).

Significant decrease in renal blood flow occurs three hours after cisplatin administration, resulting in deterioration in glomerular filtration rate (GFR). Increased sodium chloride delivery to macula densa and tubulo-glomerular 
feedback are related to an increased vascular resistance and reduced GFR (98).

The proximal renal tubules are the major site of sodium and water reabsorption (98). Cisplatin treatment causes reduction activity of ATPase, disturbed transport of water and electrolytes, mitochondrial dysfunction and altered cation balance in PTECs, leading to the decreased reabsorption of sodium and water and increased salt and water excretion (98). Accordingly, renal salt wasting syndrome occurs in $10 \%$ patients and represents one of the most usually observed complication of cisplatin therapy (99). Renal salt wasting syndrome is associated with intensive polyuria, hyponatremia, hypovolaemia, severe orthostatic hypotension, and prerenal AKI accompanied by dysfunction of the renin-aldosterone system which regulate salt and water wasting in the kidneys (98-101).

Also, cisplatin treatment may decrease the reabsorption of the filtered magnesium which causes refractory hypomagnesemia. This complication occurs in $90 \%$ of patients, and depends on the cumulative dose of administered cisplatin $(17,99)$. Having in mind that hypomagnesemia may be observed in some patients 6 years after initial cisplatin treatment, there is a possibility that cisplatin-induced hypomagnesemia has been developed in two phases. The first phase, which is manifested by malabsorption of magnesium, happens due to the cisplatin-caused damage of calcium/magnesium-sensing receptor (99), while the second phase, characterized by patchy necrosis of tubular cells, is manifested by progressive renal injury and extensive magnesium loss (99). It has to be noted that magnesium deficiency may be associated with hypokalemia and hypocalcemia and, accordingly, malignant cardiac arrhythmias and neuromuscular dysfunction may be observed in cisplatin-treated patients (99).

\section{REFERENCE}

1. Caballero M, Mackers P, Reig O, Buxo E, Navarrete $\mathrm{P}$, Blanch JL, et al. The Role of Audiometry prior to High-Dose Cisplatin in Patients with Head and Neck Cancer. Oncology. 2017;93(2):75-82. doi: 10.1159/000468522.

2. Le X, Hanna EY. Optimal regimen of cisplatin in squamous cell carcinoma of head and neck yet to be determined. Ann Transl Med. 2018;6(11):229.

3. Tepper J, Krasna MJ, Niedzwiecki D, et al. Phase III trial of trimodality therapy with cisplatin, fluorouracil, radiotherapy, and surgery compared with surgery alone for esophageal cancer: CALGB 9781. J Clin Oncol. 2008;26(7):1086-92. doi: 10.1200/JCO.2007.12.9593

4. Park JC, Citrin DE, Agarwal PK, Apolo AB. Multimodal management of muscle-invasive bladder
Renal Fanconi syndrome has also been reported in some of cisplatin-treated patients (20). This syndrome is characterized by glycosuria, urinary lack of low molecular weight proteins $(\beta 2-$ microglobulin, retinol- binding protein and $\alpha 1$ macroglobulin), aminoaciduria (loss of amino acids such as alanine, valine, leucine, methionine), proximal tubular acidosis, phosphate and potassium wasting $(97,98,102,103)$. Additionally, long-term exposure to cisplatin may result in the development of tubulointerstitial injury and interstitial fibrosis which may be life-thretening complication of cisplatin $(98,104)$.

\section{CONCLUSIONS}

Cisplatin treatment induces apoptosis and oxidative stress in PTECs eliciting strong inflammatory response in the injured kidneys. Having in mind that these cisplatin-induced effects are, at the same time, involved in anti-tumor activity of cisplatin, newly designed renoprotective strategies against cisplatin-caused nephrotoxicity should rely on the identification of the structural and functional differences between cisplatin-injured renal and tumor cells. In that way, the prevention of cisplatin-induced nephrotoxicity will not affect antitumor effects of cisplatin and will significantly improve its clinical utility.

\section{DECLARATION OF INTEREST}

None.

\section{ACKNOWLEDGEMENTS}

This study was supported by the Faculty of Medical Sciences University of Kragujevac (MP 01/18) and the Serbian Ministry of Education, Science and Technological Development (ON175069, ON175103). cancer. Curr Probl Cancer. 2014;38(3):80-108. doi: 10.1016/j.currproblcancer.2014.06.001

5. Chovanec M, Abu Zaid M, Hanna N, El-Kouri N, Einhorn LH, Albany C. Long-term toxicity of cisplatin in germ-cell tumor survivors. Ann Oncol. 2017;28(11):2670-2679. doi: 10.1093/annonc/mdx360

6. Alberts DS, Liu PY, Hannigan EV, O'Toole R, Williams SD, Young JA, et al. Intraperitoneal cisplatin plus intravenous cyclophosphamide versus intravenous cisplatin plus intravenous cyclophosphamide for stage III ovarian cancer. N Engl J Med. 1996 Dec 26;335(26):1950-5.

7. Colombo N, Creutzberg C, Amant F, et al. ESMOESGO-ESTRO Consensus Conference on Endometrial Cancer: Diagnosis, Treatment and Follow-up. Int J Gynecol Cancer. 2015;26(1):2-30. doi: 10.1097/IGC. 0000000000000609 
8. Rose PG, Bundy BN, Watkins EB, Thigpen JT, Deppe G, Maiman MA, et al. Concurrent cisplatin-based radiotherapy and chemotherapy for locally advanced cervical cancer. $\mathrm{N}$ Engl J Med. 1999 Apr 15;340(15):1144-53.DOI: 10.1056/NEJM199904153 401502

9. Islam SS, Al-Sharif I, Sultan A, Al-Mazrou A, Remmal A, Aboussekhra A. Eugenol potentiates cisplatin anti-cancer activity through inhibition of ALDHpositive breast cancer stem cells and the NF- $\mathrm{B}$ signaling pathway. Mol Carcinog. 2018 Mar;57(3):333-346. doi: 10.1002/mc.22758.

10. Orditura M, Galizia G, Sforza V, et al. Treatment of gastric cancer. World J Gastroenterol. 2014;20(7):1635-49. doi: 10.3748/wjg.v20.i7.1635

11. Fennell DA, Summers Y, Cadranel J, Benepal T, Christoph DC, Lal R, et al. Cisplatin in the modern era: The backbone of first-line chemotherapy for non-small cell lung cancer. Cancer Treat Rev. 2016 Mar;44:4250. doi: 10.1016/j.ctrv.2016.01.003.

12. Li H, Wang H, Deng K, Han W, Hong B, Lin W. The ratio of $\mathrm{Bcl}-2 / \mathrm{Bim}$ as a predictor of cisplatin response provides a rational combination of ABT-263 with cisplatin or radiation in small cell lung cancer. Cancer Biomark. 2018 Dec 25. doi: 10.3233/CBM-181692.

13. Dasari S, Tchounwou PB. Cisplatin in cancer therapy: molecular mechanisms of action. Eur J Pharmacol. 2014 Oct 5; 0: 364-378. doi: 10.1016/j.ejphar.2014.07.025

14. Hartmann JT, Lipp HP. Toxicity of platinum compounds. Expert Opin Pharmacother. 2003 Jun;4(6):889-901. doi: 10.1517/14656566.4.6.889

15. Kobayashi R, Suzuki A, Matsuura K, Yamada N, Nakano M, Deguchi T, et al. Risk analysis for cisplatin-induced nephrotoxicity during first cycle of chemotherapy. Int J Clin Exp Med. 2016;9(2):3635-41.

16. Tucker BM, Perazella MA. Medications. In: Lerma EV, Sparks MA, and Topf J. Nephrology Secrets. 4th ed. Philadelphia, PA:Elsevier;2018. p.78-83.

17. Perazella MA. Onco-Nephrology: Renal Toxicities of Chemotherapeutic Agents. Clin J Am Soc Nephrol. 2012 Oct;7(10):1713-21. doi: 10.2215/CJN.02780312.

18. Pabla N, Dong Z. Cisplatin nephrotoxicity: Mechanisms and renoprotective strategies. Kidney Int. 2008 May;73(9):994-1007. doi: 10.1038/sj.ki.5002786

19. Dos Santos NA, Carvalho Rodrigues MA, Martins NM, dos Santos AC. Cisplatin-induced nephrotoxicity and targets of nephroprotection: an update. Arch Toxicol. 2012 Aug;86(8):1233-50. doi: 10.1007/s00204012-0821-7

20. Miller RP, Tadagavadi RK, Ramesh G, Reeves WB. Mechanisms of Cisplatin nephrotoxicity.Toxins (Basel). 2010 Nov;2(11):2490-518. doi: 10.3390/toxins2112490.

21. Yao X, Panichpisal K, Kurtzman N, Nugent K. Cisplatin Nephrotoxicity: A Review. Am J Med Sci. 2007 Aug;334(2):115-24.

doi: 10.1097/MAJ.0b013e31812dfe1e

22. Bolisetty S, Traylor A, Joseph R, Zarjou A, Agarwal A. Proximal tubule-targeted heme oxygenase- 1 in cisplatin-induced acute kidney injury. Am J Physiol Renal Physiol. 2016 Mar 1; 310(5): F385-F394. doi:10.1152/ajprenal.00335.2015.

23. Ciarimboli G. Membrane Transporters as Mediators of Cisplatin Side Effects. Anticancer Res. 2014 Jan;34(1):547-50.

24. Pabla N, Murphy RF, Liu K, Dong Z. The copper transporter Ctr1 contributes to cisplatin uptake by renal tubular cells during cisplatin nephrotoxicity. Am J Physiol Renal Physiol. 2009 Mar;296(3):F505-11. doi: 10.1152/ajprenal.90545.2008.

25. Filipski KK, Mathijssen RH, Mikkelsen TS, Schinkel AH, Sparreboom A. Contribution of organic cation transporter 2 (OCT2) to cisplatin-induced nephrotoxicity. Clin Pharmacol Ther. 2009 Oct;86(4):396-402. doi: 10.1038/clpt.2009.139.

26. Ciarimboli G, Deuster D, Knief A, et al. Organic Cation Transporter 2 Mediates Cisplatin-Induced Oto- and Nephrotoxicity and Is a Target for Protective Interventions. Am J Pathol. 2010 Mar; 176(3): 1169-1180. doi: 10.2353/ajpath.2010.090610.

27. Townsend DM, Deng M, Zhang L, Lapus MG, Hanigan $\mathrm{MH}$. Metabolism of Cisplatin to a nephrotoxin in proximal tubule cells.J Am Soc Nephrol. 2003 Jan;14(1):1-10.

28. Basu A, Krishnamurthy S. Cellular responses to cisplatin-induced DNA damage. J Nucleic Acids. 2010 Aug 8;2010. pii: 201367. doi: 10.4061/2010/201367.

29. Price PM, Safirstein RL, Megyesi J. Protection of renal cells from cisplatin toxicity by cell cycle inhibitors. Am J Physiol Renal Physiol. 2004 Feb;286(2):F37884. doi: 10.1152/ajprenal.00192.2003

30. Megyesi J, Safirstein RL, Price PM. Induction of p21WAF1/CIP1/SDI1 in kidney tubule cells affects the course of cisplatin-induced acute renal failure. J Clin Invest. 1998 Feb 15; 101(4): 777-782. doi: 10.1172/JCI1497.

31. Zhou H, Kato A, Yasuda H, Miyaji T, Fujigaki Y, Yamamoto $\mathrm{T}$, et al. The induction of cell cycle regulatory and DNA repair proteins in cisplatin-induced acute renal failure. Toxicol Appl Pharmacol. 2004 Oct 15;200(2):111-20. doi: 10.1016/j.taap.2004.04.003

32. Price PM, Yu F, Kaldis P, et al. Dependence of Cisplatin-Induced Cell Death In Vitro and In Vivo on CyclinDependent Kinase 2. J Am Soc Nephrol. 2006 Sep;17(9):2434-42. Epub 2006 Aug 16. doi: 10.1681/ASN.2006020162.

33. Siddik Z. Cisplatin: mode of cytotoxic action and molecular basis of resistance. Oncogene. 2003 Oct 20;22(47):7265-79. doi: 10.1038/sj.onc.1206933.

34. Anderson B, Murray D. Clinically relevant resistance in cancer chemotherapy. Dordrecht : Kluwer Academic Publishers; 2002.

35. Schieber M, Chandel NS. ROS Function in Redox Signaling and Oxidative Stress. Curr Biol. 2014 May 19;24(10):R453-62. doi: 10.1016/j.cub.2014.03.034.

36. Baliga R, Zhang Z, Baliga M, Ueda N, Shah SV. Role of cytochrome P-450 as a source of catalytic iron in cisplatin-induced nephrotoxicity. Kidney Int. 1998 Nov;54(5):1562-9. doi: 10.1046/j.1523-1755.1998.00 161.x

37. Kruidering M, Van de Water B, de Heer E, Mulder GJ, Nagelkerke J. Cisplatin-induced nephrotoxicity in porcine proximal tubular cells: mitochondrial dysfunction by inhibition of complexes I to IV of the respiratory chain.J Pharmacol Exp Ther. 1997 Feb;280(2):638-49. 

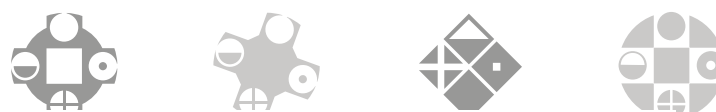

38. Durak I, Ozbek H, Karaayvaz M, Oztürk HS. Cisplatin induces acute renal failure by impairing antioxidant system in guinea pigs: effects of antioxidant supplementation on the cisplatin nephrotoxicity.Drug Chem Toxicol. 2002 Feb;25(1):1-8. doi:10.1081/DCT100108468

39. Appenroth D, Fröb S, Kersten L, Splinter FK, Winnefeld K. Protective effects of vitamin E and C on cisplatin nephrotoxicity in developing rats. Arch Toxicol. 1997;71(11):677-83.

40. Davis CA, Nick HS, Agarwal A. Manganese superoxide dismutase attenuates Cisplatin-induced renal injury: importance of superoxide. J Am Soc Nephrol. 2001 Dec;12(12):2683-90.

41. Yildirim Z, Sogut S, Odaci E, Iraz M, Ozyurt H, Kotuk M, Akyol O. Oral erdosteine administration attenuates cisplatin-induced renal tubular damage in rats. Pharmacol Res. 2003 Feb;47(2):149-56.

42. Ozkok A, Edelstein CL. Pathophysiology of cisplatininduced acute kidney injury. Biomed Res Int. 2014;2014:967826. doi: 10.1155/2014/967826.

43. Lee RH, Song JM, Park MY, Kang SK, Kim YK, Jung JS. Cisplatin-induced apoptosis by translocation of endogenous Bax in mouse collecting duct cells. Biochem Pharmacol. 2001 Oct 15;62(8):1013-23.

44. Wei Q, Dong G, Franklin J, Dong Z. The pathological role of Bax in cisplatin nephrotoxicity. Kidney Int. 2007 Jul;72(1):53-62. doi: 10.1038/sj.ki.5002256

45. Seth R, Yang C, Kaushal V, Shah SV, Kaushal GP. p53-dependent caspase-2 activation in mitochondrial release of apoptosis-inducing factor and its role in renal tubular epithelial cell injury.J Biol Chem. 2005 Sep 2;280(35):31230-9. doi: 10.1074/jbc.M503305200

46. Yin X, Apostolov EO, Shah SV, Wang X, Bogdanov $\mathrm{KV}$, Buzder T, et al. Induction of renal endonuclease $\mathrm{G}$ by cisplatin is reduced in DNase I-deficient mice. J Am Soc Nephrol. 2007 Sep;18(9):2544-53. doi: 10.1681/ASN.2006080896

47. Kaushal GP, Kaushal V, Hong X, Shah SV. Role and regulation of activation of caspases in cisplatin-induced injury to renal tubular epithelial cells. Kidney Int. 2001 Nov;60(5):1726-36. doi: 10.1046/j.15231755.2001.00026.x

48. Cummings BS, McHowat J, Schnellmann RG. Role of an endoplasmic reticulum $\mathrm{Ca} 2+$-independent phospholipase A2 in cisplatin-induced renal cell apoptosis. J Pharmacol Exp Ther. 2004 Mar;308(3):921-8. doi: 10.1124/jpet.103.060541

49. Liu H, Baliga R. Endoplasmic reticulum stress-associated caspase 12 mediates cisplatin-induced LLC-PK1 cell apoptosis. J Am Soc Nephrol. 2005 Jul;16(7):1985-92. doi: 10.1681/ASN.2004090768

50. Boyce M, Yuan J. Cellular response to endoplasmic reticulum stress: a matter of life or death. Cell Death Differ. 2006 Mar;13(3):363-73. doi: 10.1038/sj.cdd.4401817

51. Arany I, Megyesi JK, Kaneto H, Price PM, Safirstein RL. Cisplatin-induced cell death is EGFR/src/ERK signaling dependent in mouse proximal tubule cells. Am J Physiol Renal Physiol. 2004 Sep;287(3):F543-9. doi: 10.1152/ajprenal.00112.2004

52. Clark JS, Faisal A, Baliga R, Nagamine Y, Arany I. Cisplatin induces apoptosis through the ERK-p66shc
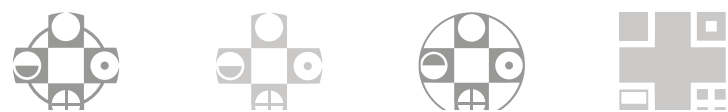

pathway in renal proximal tubule cells. Cancer Lett. 2010 Nov 28;297(2):165-70. doi: 10.1016/j.canlet.2010.05.007

53. Jiang M, Dong Z. Regulation and pathological role of p53 in cisplatin nephrotoxicity.J Pharmacol Exp Ther. 2008 Nov;327(2):300-7. doi: 10.1124/jpet.108.139162

54. Jiang M, Wei Q, Wang J, Du Q, Yu J, Zhang L, Dong Z. Regulation of PUMA-alpha by p53 in cisplatin-induced renal cell apoptosis. Oncogene. $2006 \mathrm{Jul}$ 6;25(29):4056-66. doi: 10.1038/sj.onc.1209440

55. Han X, Yue J, Chesney RW. Functional TauT protects against acute kidney injury.J Am Soc Nephrol. 2009 Jun;20(6):1323-32. doi: 10.1681/ASN.2008050465

56. Periyasamy-Thandavan S, Jiang M, Wei Q, Smith R, Yin XM, Dong Z. Autophagy is cytoprotective during cisplatin injury of renal proximal tubular cells. Kidney Int. 2008 Sep;74(5):631-40. doi: 10.1038/ki.2008.214

57. Kaushal GP, Shah SV. Autophagy in acute kidney injury.Kidney Int. 2016 Apr;89(4):779-91. doi: 10.1016/j.kint.2015.11.021.

58. Takahashi A, Kimura T, Takabatake Y, Namba T, Kaimori J, Kitamura H, et al. Autophagy guards against cisplatin-induced acute kidney injury. Am J Pathol. 2012 Feb;180(2):517-25. doi: 10.1016/j.ajpath.2011.11.001

59. Yang C, Kaushal V, Shah SV, Kaushal GP. Autophagy is associated with apoptosis in cisplatin injury to renal tubular epithelial cells. Am J Physiol Renal Physiol. 2008 Apr;294(4):F777-87. doi: 10.1152/ajprenal.00590.2007

60. Jiang M, Wei Q, Dong G, Komatsu M, Su Y, Dong Z. Autophagy in proximal tubules protects against acute kidney injury. Kidney international. 2012;82(12):1271-1283. doi:10.1038/ki.2012.261

61. Inoue K, Kuwana H, Shimamura Y, Ogata K, Taniguchi Y, Kagawa T,et al. Cisplatin-induced macroautophagy occurs prior to apoptosis in proximal tubules in vivo. Clin Exp Nephrol. 2010 Apr;14(2):112-22. doi: 10.1007/s10157-009-0254-7

62. Jiang M, Dong Z. Self-eating for death or survival during cisplatin nephrotoxicity?Clin Exp Nephrol. 2010 Oct;14(5):516-7. doi: 10.1007/s10157-010-0324-x.

63. Anders HJ. Necroptosis in Acute Kidney Injury.Nephron. 2018;139(4):342-348. doi: 10.1159/000489940.

64. Tristao VR, Goncalves PF, Dalboni MA, Batista MC, Durao Mde S Jr., Monte JC. Nec-1 protects against nonapoptotic cell death in cisplatin-induced kidney injury. Ren Fail. 2012;34(3):373-7. doi: 10.3109/0886022X.2011.647343.

65. Ramesh G, Reeves WB. TNF-alpha mediates chemokine and cytokine expression and renal injury in cisplatin nephrotoxicity. J Clin Invest. 2002 Sep;110(6):835-42. doi: 10.1172/JCI15606

66. Liu M, Chien CC, Burne-Taney M, Molls RR, Racusen LC, Colvin RB, et al. A pathophysiologic role for $\mathrm{T}$ lymphocytes in murine acute cisplatin nephrotoxicity. J Am Soc Nephrol. 2006 Mar;17(3):765-74. doi: 10.1681/ASN.2005010102

67. Cenedeze MA, Gonçalves GM, Feitoza CQ, Wang PM, Damião MJ, Bertocchi AP, et al. The role of tolllike receptor 4 in cisplatin-induced renal injury. Transplant Proc. 2007 Mar;39(2):409-11. doi: 10.1016/j.transproceed.2007.01.032 
TLR4 signaling mediates inflammation and tissue injury in nephrotoxicity.J Am Soc Nephrol. 2008 May;19(5):923-32. doi: 10.1681/ASN.2007090982.

69. Chan AJ, Alikhan MA, Odobasic D, Gan PY, Khouri MB, Steinmetz OM, et al. Innate IL-17A-producing leukocytes promote acute kidney injury via inflammasome and Toll-like receptor activation.Am J Pathol. 2014 May;184(5):1411-8. doi: 10.1016/j.ajpath.2014.01.023.

70. Dong Z, Atherton SS. Tumor necrosis factor-alpha in cisplatin nephrotoxicity: a homebred foe? Kidney Int. 2007 Jul;72(1):5-7. doi: 10.1038/sj.ki.5002320

71. Locksley RM, Killeen N, Lenardo MJ.The TNF and TNF receptor superfamilies: integrating mammalian biology. Cell. 2001 Feb 23;104(4):487-501. doi: 10.1016/S0092-8674(01)00237-9

72. Ramesh G, Reeves WB. TNFR2-mediated apoptosis and necrosis in cisplatin-induced acute renal failure. Am J Physiol Renal Physiol. 2003 Oct;285(4):F610-8. doi: 10.1152/ajprenal.00101.2003

73. Ramesh G, Reeves WB. p38 MAP kinase inhibition ameliorates cisplatin nephrotoxicity in mice. Am J Physiol Renal Physiol. 2005 Jul;289(1):F166-74. doi: 10.1152/ajprenal.00401.2004

74. Ramesh G, Reeves WB. Cisplatin increases TNFalpha mRNA stability in kidney proximal tubule cells. Ren Fail. 2006;28(7):583-92. doi: 10.1080/08860220600843839

75. Ramesh G, Zhang B, Uematsu S, Akira S, Reeves WB. Endotoxin and cisplatin synergistically induce renal dysfunction and cytokine production in mice. Am J Physiol Renal Physiol. 2007 Jul;293(1):F325-32. doi: 10.1152/ajprenal.00158.2007

76. Zhang B, Ramesh G, Norbury CC, Reeves WB. Cisplatin-induced nephrotoxicity is mediated by tumor necrosis factor-alpha produced by renal parenchymal cells. Kidney Int. 2007 Jul;72(1):37-44. doi: 10.1038/sj.ki.5002242

77. Kelly KJ, Meehan SM, Colvin RB, Williams WW, Bonventre JV. Protection from toxicant-mediated renal injury in the rat with anti-CD54 antibody. Kidney Int. 1999 Sep;56(3):922-31. doi: 10.1046/j.15231755.1999.00629.x

78. Tadagavadi RK, Reeves WB. Endogenous IL-10 attenuates cisplatin nephrotoxicity: role of dendritic cells. J Immunol. 2010 Oct 15;185(8):4904-11. doi: 10.4049/jimmunol.1000383

79. Akcay A, Nguyen Q, He Z, et al. IL-33 Exacerbates Acute Kidney Injury.J Am Soc Nephrol. 2011 Nov; 22(11): 2057-2067. doi: 10.1681/ASN.2010091011

80. Deng J, Kohda Y, Chiao H, Wang Y, Hu X, Hewitt $\mathrm{SM}$, et al. Interleukin-10 inhibits ischemic and cisplatin-induced acute renal injury. Kidney Int. 2001 Dec;60(6):2118-28. doi: 10.1046/j.1523-1755.2001 .00043.x

81. Kim H, Lee H, Lee G, Jang H, Kim SS, Yoon H, et al. Phospholipase A2 inhibits cisplatin-induced acute kidney injury by modulating regulatory $\mathrm{T}$ cells by the CD206 mannose receptor. Kidney Int. 2015 Sep;88(3):550-9. doi: 10.1038/ki.2015.147.

82. Summers SA, Chan J, Gan P-Y, et al. Mast Cells Mediate Acute Kidney Injury through the Production of

TNF. J Am Soc Nephrol. 2011 Dec; 22(12): 22262236. doi: 10.1681/ASN.2011020182.

83. Wang Y, Thorlacius H. Mast cell-derived tumour necrosis factor-alpha mediates macrophage inflammatory protein-2-induced recruitment of neutrophils in mice. Br J Pharmacol. 2005 Aug;145(8):1062-8. doi: 10.1038/sj.bjp.0706274

84. Faubel S, Lewis EC, Reznikov L, Ljubanovic D, Hoke TS, Somerset H, et al. Cisplatin-induced acute renal failure is associated with an increase in the cytokines interleukin (IL)-1beta, IL-18, IL-6, and neutrophil infiltration in the kidney. J Pharmacol Exp Ther. 2007 Jul;322(1):8-15. doi: 10.1124/jpet.107.119792

85. Faubel S, Ljubanovic D, Reznikov L, Somerset H, Dinarello CA, Edelstein CL. Caspase-1-deficient mice are protected against cisplatin-induced apoptosis and acute tubular necrosis.Kidney Int. 2004 Dec;66(6):2202-13. doi: 10.1111/j.1523-1755.2004. 66010.x

86. Tadagavadi R, Reeves WB. Neutrophils in cisplatin AKI-mediator or marker? Kidney Int. 2017 Jul;92(1):11-13. doi: 10.1016/j.kint.2017.03.023.

87. Ramesh G, Reeves WB. Salicylate reduces cisplatin nephrotoxicity by inhibition of tumor necrosis factoralpha.Kidney Int. 2004 Feb;65(2):490-9. doi: 10.1111/ j.1523-1755.2004.00413.x

88. Tadagavadi RK, Gao G, Wang WW, Gonzalez MR, Reeves WB. Dendritic Cell Protection from Cisplatin Nephrotoxicity Is Independent of Neutrophils. Toxins (Basel). 2015 Aug 19;7(8):3245-56. doi: 10.3390/toxins7083245.

89. Tarang S, Sodhi A, Chauhan P. Differential expression of Toll-like receptors in murine peritoneal macrophages in vitro on treatment with cisplatin.Int Immunol. 2007 May;19(5):635-43. doi: 10.1093/intimm/dxm029

90. Inoue T. M1 macrophage triggered by Mincle leads to a deterioration of acute kidney injury. Kidney Int. 2017 Mar;91(3):526-529. doi: 10.1016/j.kint.2016.11.026.

91. Li J, Tang Y, Tang PMK, Lv J, Huang XR, CarlssonSkwirut C, et al. Blocking Macrophage Migration Inhibitory Factor Protects Against Cisplatin-Induced Acute Kidney Injury in Mice. Mol Ther. 2018 Oct 3;26(10):2523-2532. doi: 10.1016/j.ymthe.2018.07. 014.

92. Jang HR, Rabb H. Immune cells in experimental acute kidney injury. Nat Rev Nephrol. 2015 Feb;11(2):88101. doi: 10.1038/nrneph.2014.180.

93. Nozaki Y, Nikolic-Paterson DJ, Yagita H, Akiba H, Holdsworth SR, Kitching AR. Tim-1 promotes cisplatin nephrotoxicity.Am J Physiol Renal Physiol. 2011 Nov;301(5):F1098-104. doi: 10.1152/ajprenal. 00193. 2011.

94. Tadagavadi RK, Reeves WB. Renal Dendritic Cells Ameliorate Nephrotoxic Acute Kidney Injury. J Am Soc Nephrol. 2010 Jan; 21(1): 53-63. doi: 10.1681/ASN.2009040407

95. Okusa MD, Li L. Dendritic Cells in Acute Kidney Injury: Cues from the Microenvironment. Trans Am Clin Climatol Assoc. 2012; 123: 54-63.

96. Lee H, Nho D, Chung HS, Lee H, Shin MK, Kim SH, et al. CD4+CD25+ regulatory $\mathrm{T}$ cells attenuate 
cisplatin-induced nephrotoxicity in mice. Kidney Int. 2010 Dec;78(11):1100-9. doi: 10.1038/ki.2010.139.

97. Portilla D, Safar AM, Shannon MI, et al. Cisplatin nephrotoxicity. www.uptodate.com/cisplatin_nephrotoxicity. Date last accessed: January 5, 2019. Date last updated: Feb 14, 2018.

98. Glezerman IG, Jaimes EA. Chapter 11. Chemotherapy and Kidney Injury. American Society of Nephrology Onco-Nephrology Curriculum [Internet]. 2016 [cited 2019 Jan 05]. p. 1-10. Available from: https://www.asn-online.org/education/distancelearning/curricula/onco/Chapter11.pdf

99. Lajer H, Daugaard G. Cisplatin and hypomagnesemia. Cancer Treat Rev. 1999 Feb;25(1):47-58. doi: 10.1053 /ctrv.1999.0097

100.Hutchison FN, Perez EA, Gandara DR, Lawrence HJ, Kaysen GA. Renal salt wasting in patients treated with cisplatin. Ann Intern Med. 1988 Jan;108(1):21-5.
101.Hamdi T, Latta S, Jallad B, Kheir F, Alhosaini MN, Patel A. Cisplatin-induced renal salt wasting syndrome. South Med J. 2010 Aug;103(8):793-9. doi: 10.1097/SMJ.0b013e3181e63682.

102.Hall AM, Bass P, Unwin RJ. Drug-induced renal Fanconi syndrome. QJM. 2014 Apr;107(4):261-9. doi: 10.1093/qjmed/hct258.

103. Sirac C, Bridoux F, Essig M, Devuyst O, Touchard G, Cogné M. Toward understanding renal Fanconi syndrome: step by step advances through experimental models. Contrib Nephrol. 2011;169:247-61. doi: 10.1159/000313962

104.Wood PA, Hrushesky WJ. Cisplatin-associated anemia: an erythropoietin deficiency syndrome. J Clin Invest. 1995 Apr;95(4):1650-9. doi: 10.1172/ JCI117840 